Magdalena MagiersKa-KRZYSZToŃ

Uniwersytet Medyczny im. Karola Marcinkowskiego

$w$ Poznaniu

Magdalena OlempSKa-Wysocka

Uniwersytet im. Adama Mickiewicza

w Poznaniu

\title{
WSZCZEP ŚLIMAKOWY \\ DLA PACJENTÓW Z GŁUCHOTĄ POSTLINGWALNĄ - SZANSA NA POPRAWĘ JAKOŚCI ŻYCIA
}

\begin{abstract}
Aвstract. Magierska-Krzysztoń Magdalena, Olempska-Wysocka Magdalena, Wszczep ślimakowy dla pacjentów z głuchota postlingwalna - szansa na poprawę jakości życia [A Cochlear Implant for Patients with Postlingual Deafness - a Chance to Improve the Quality of Life ]. Studia Edukacyjne nr 48, 2018, Poznań 2018, pp. 249-258. Adam Mickiewicz University Press. ISSN 1233-6688. DOI: 10.14746/ se.2018.48.16

Permanent hearing damage, which was diagnosed in the postlingling period - prevents "normal" life. Adult, mature people who until now had certain social roles and activities, suddenly experienced the phenomenon of exclusion as a result of hearing loss, which leads in many cases to personal dramas. The aim of the research was to determine the possibility of improving the quality of life of patients with postlingual deafness after implanting the cochlear implant. The study involved 96 patients aged 30-75 years, postlingally deaf, equipped with a cochlear implant. The study used the CES-D questionnaire, the PANAS-PL questionnaire and the diagnostic survey method (questionnaire survey). The results of the study show that in the majority of patients after implantation, there was a subjectively evaluated improvement associated with activity in various spheres of life. The use of the cochlear implant in post-lethal hearing impaired patients allowed to achieve satisfactory auditory functioning, which contributed to the improvement of the quality of life.
\end{abstract}

Key words: quality of live, cochlear implant, postlingual deafness

\section{Wprowadzenie}

Pojęcie jakości życia może być rozumiane obiektywnie i subiektywnie. Subiektywnie rozumiana jakość życia stanowi wynik oceny i wartościowania 
różnych sfer życia traktowanych jako całość, może mieć charakter poznawczy i mierzona jest poczuciem satysfakcji albo też ma charakter bardziej emocjonalno-przeżyciowy, stanowiąc o poziomie zadowolenia z różnych sfer jakości życia. Obiektywnie pojmowana jakość życia stanowi zespół warunków życia, a także działania człowieka, obejmując środowisko fizyczne, materialne i społeczno-kulturowe ${ }^{1}$. Janusz Czapiński utożsamia jakość życia z pojęciem dobrostanu lub szczęścia. W koncepcji tej wskaźniki obiektywne odnoszą się do warunków życia, natomiast subiektywne - do społecznych, materialnych, środowiskowych, zdrowotnych ocen wartościujących dotyczących własnego życia obecnego, przeszłego i przyszłego. W jego skład wchodzą także wskaźniki woli życia i pragnienie życia ${ }^{2}$. Według Stanisława Kowalika, jakość życia można rozumieć dwojako: jako odczucie własnego życia poprzez poznawanie albo jako odczucie własnego życia poprzez przeżywanie go. Jakość życia może być zatem postrzegana w wymiarze refleksji dotyczącej przebiegu i aktualnego stanu własnego życia, a także doświadczania różnych stanów psychicznych podczas życia. Główne narzędzie do oceny jakości własnego życia stanowi świadomość refleksyjna. Jak wskazuje Kowalik, jest ona zbiorem przekonań, wątpliwości dotyczących własnego życia. Poprzez stosowanie świadomości refleksyjnej człowiek odnosi się do własnego życia z pewnej perspektywy. Przeżywanie choroby będzie zatem możliwe tak długo, jak długo nie zostanie ona uznana za naturalny atrybut człowieka. Przeżywanie umożliwia także dostęp do podstawowej kategorii danych o własnym życiu, jest oparte wyłącznie na konkretnym doświadczeniu jednostki i jest bierne ${ }^{3}$. Odwołując się do koncepcji Kurta Lewina, nabycie niepełnosprawności przez jednostkę stanowi zmianę pojawiającą się w jej przestrzeni życiowej. Konsekwencje takiej zmiany mogą być różnorodne. Mogą dotyczyć zablokowania dostępu do niektórych regionów przestrzeni życiowej, co jest równoznaczne z jej ograniczeniem. Mogą także dotyczyć wzrostu napięcia w całej przestrzeni życiowej ze względu na przeszkody wynikające $\mathrm{z}$ utrudnień $\mathrm{w}$ zaspokojeniu własnych potrzeb przez osobę z niepełnosprawnością, a także może pojawić się ograniczenie aktywności życiowej ze względu na uszkodzenie obszaru percepcyjno-motorycznego jednostki. Jak wskazuje Lewin, osoba niepełnosprawna żyje w stanie podwyższonego napięcia spowodowanego trudnościami w dostępie do takich wartości, które pozwoliłyby zaspokoić jej potrzeby. Bark dostępu do określonych regionów przestrzeni życiowej może znacznie ograniczyć jej aktywność, a postępując dalej - może pogłębiać uszkodzenie

\footnotetext{
${ }^{1}$ Psychologia kliniczna, red. L. Cierpiałkowska, H. Sęk, Warszawa 2005, s. 58.

${ }^{2}$ J. Czapiński, Psychologia szczęścia - przegląd badań teorii cebulowej, Warszawa - Poznań 1992.

${ }^{3}$ S. Kowalik, Pomiar jakości życia - kontrowersje teoretyczne, [w:] Pomiar i poczucie jakości życia u aktywnych zawodowo i bezrobotnych, red. A. Bańka, R. Derbis, Poznań 1995.
} 
przestrzeni życiowej. Koncepcja ta zakłada, że istniejący w przestrzeni życiowej dynamiczny układ powoduje, że utrata równowagi w tym obrębie jest bardzo zindywidualizowana. Zatem, każda osoba niepełnosprawna wymaga zupełnie innych form pomocy psychologicznej ${ }^{4}$. Agnieszka Dziurowicz-Kozłowska zaznacza, że każdy sposób konceptualizacji jakości życia, który jest uwarunkowany stanem zdrowia odnosi się do trzech istotnych obszarów. Są to: obszar uczuć, funkcjonowania oraz przyszłości. Pierwszy odnosi się do subiektywnego odczucia dobrostanu jednostki we wszystkich sferach życia; obszar funkcjonowania dotyczy aktywności poznawczej, fizycznej i interpersonalnej podmiotu, a obszar przyszłości związany jest z prognozowaniem zmian, jakie mogą dokonać się w dwóch pierwszych obszarach ${ }^{5}$.

\section{Materiał i metody}

W badaniach wzięło udział 96 dorosłych pacjentów z głuchotą postlingwalną (51 kobiet i 45 mężczyzn). Operację wszczepienia implantu ślimakowego przeprowadzono w Klinice Otolaryngologii i Onkologii Laryngologicznej Uniwersytetu Medycznego w Poznaniu. Wszyscy pacjenci wyposażeni są w implant ślimakowy Nucleus australijskiej firmy Cochlear. Wiek pacjentów w chwili implantacji wynosił od 30 do 75 lat, co zgodne jest z ideą Programu Leczenia Głuchoty Metodą Wszczepów Ślimakowych, który między innymi zakłada, że implantacja w grupie dorosłych, ogłuchłych postlingwalnie może przyczynić się do polepszenia jakości życia ${ }^{6}$. Podstawą zakwalifikowania do operacji były wskazania audiologiczne z powodu obustronnej głuchoty lub obustronnego niedosłuchu typu odbiorczego. Przyczyną występowania głuchoty w badanej grupie był najczęściej postępujący niedosłuch, urazy, choroby, zażywanie leków ototoksycznych oraz nagłe głuchoty o podłożu idiopatycznym. Czas użytkowania wszczepu ślimakowego wynosił minimum 2 lata. Największą grupę stanowili pacjenci z wykształceniem: średnim (62\%), zawodowym (20\%), podstawowym (8\%) oraz wyższym $(10 \%)$. Około $50 \%$ badanej grupy stanowiły osoby w wieku między 35 a 60 lat, będące w okresie wzmożonej aktywności zawodowej, która wymuszała niejako bardzo dobre funkcjonowanie słuchowe oraz językowe. Większość pacjentów pozostawała w stałych związkach, posiadając często już dorosłe dzieci (75\%). Pozostali pacjenci określali siebie jako osoby stanu wolnego. Czynne uczestnictwo

${ }^{4}$ S. Kowalik, Stosowana psychologia rehabilitacji, Warszawa 2018, s. 80-81.

5 A. Dziurowicz-Kozłowska, Stosowana psychologia rehabilitacji, Warszawa 2018, s. 77-99.

${ }^{6}$ J. Kobosko, W. Jędrzejczak, Satisfaction With Cochlear Implants in Postlingually Deaf Adults and Its Nonaudiological Predictors: Psychological Distress, Coping Strategies and Self Esteem, Ear Hear, 2015 September-October, 36(5), s. 605-618. 
$\mathrm{w}$ procesie rehabilitacji pooperacyjnej (systematyczna terapia głosu, słuchu, mowy, fittingi - sesje ustawienia procesora mowy) deklarowało 79 pacjentów. Wszyscy pacjenci byli w normie intelektualnej. W badaniach wykorzystano kwestionariusz PANAS-PL (Positive and Negative Affect Schedule) autorstwa Davida Watsona oraz Lee Anny Clark 7 . Zadanie pacjentów polegało na wypełnieniu kwestionariusza, w którym należało udzielić odpowiedzi na 20 pytań dotyczących odczuwania stanów emocjonalnych związanych z utratą słuchu - jeszcze przed implantacją oraz po zaimplantowaniu. W kwestionariuszu użyto 5-stopniowej skali służącej do opisywania oraz definiowania negatywnych i pozytywnych wpływów (współczynnik spójności wewnętrznej alpha Cronbach $=0,83$ ). Drugim narzędziem, którym posłużono się w badaniach był kwestionariusz CES-D (Center of Epidemiological Studies Depression Test), którego

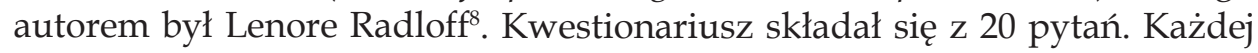
odpowiedzi przypisana jest określona liczba punktów (od 0 do 3). Narzędzie służy do oceny samopoczucia badanych po utracie słuchu oraz $\mathrm{w}$ okresie pooperacyjnym, kiedy pacjent staje się czynnym użytkownikiem wszczepu ślimakowego. Wskaźnikiem mogącym świadczyć o występowaniu symptomów depresji jest wybieranie przez pacjentów odpowiedzi „często” oraz "zawsze". Autorzy kwestionariusza uważają, że uzyskana suma punktów powyżej 16 może świadczyć o występowaniu objawów depresji. Dodatkowo posłużono się badaniami ankietowymi, które z subiektywnej perspektywy każdego pacjenta dotyczyły wpływu implantacji na jakość życia. Pytania zawarte $\mathrm{w}$ ankiecie odnosiły się do zmian, jakie zaszły w codziennym życiu (w obszarach: sfera rodzinna - relacje z najbliższymi osobami, sfera zawodowa, sfera kontaktów społecznych - kontakty ze znajomymi i przyjaciółmi, czas wolny) po utracie słuchu oraz po zaimplantowaniu. Uzyskane odpowiedzi pogrupowano $\mathrm{w}$ trzech kategoriach danych, które należy interpretować jako: poprawę jakości życia po implantacji, brak jakichkolwiek zmian oraz pogorszenie jakości życia po zaimplantowaniu.

\section{Wyniki}

Uzyskane wyniki badania przeprowadzonego kwestionariuszem CES-D w grupie wytypowanych pacjentów wskazują, że ponad $80 \%$ badanych wykazywało objawy depresji (tab. 1). Czas borykania się z konsekwencjami związanymi z utratą słuchu był tak trudny i bolesny dla większości, że pacjenci w przeważającej części deklarowali negatywne myśli i odczucia doty-

${ }^{7}$ D. Watson, L.A. Clark, The PANAS-X: Manual for the positive and negative affect schedule, Expanded form, Iowa City 1994.

${ }^{8}$ L. Radloff, The CES-D Scale: A self-report depression for research in general population, Appl. Psychol. Measur., 1977, 1, 3, s. 385-401. 
czące życia po ogłuchnięciu, w świecie ciszy. Przyszłość bez możliwości słyszenia i porozumiewania się na drodze słuchowej jawiła się jako niemożliwa do zaakceptowania.

Funkcjonowanie badanych po utracie słuchu - CES-D

\begin{tabular}{|l|c|}
\hline \multicolumn{1}{|c|}{$\begin{array}{c}\text { Funkcjonowanie badanych } \\
\text { po utracie słuchu }\end{array}$} & Liczba pacjentów \\
\hline Brak depresji & 18 \\
\hline Objawy depresji & 78 \\
\hline
\end{tabular}

Wyniki uzyskane przez pacjentów w tym samym okresie w kwestionariuszu PANAS-PL wyglądają bardzo podobnie (tab. 2). Uczucia i emocje negatywne towarzyszyły badanej grupie praktycznie przez większość dnia, powodując, że zawstydzenie, niepewność, przestrach, czy nadmierna nerwowość całkowicie zdominowały codzienne życie.

Tabela 2

Funkcjonowanie badanych po utracie słuchu PANAS-PL

\begin{tabular}{|l|c|}
\hline \multicolumn{1}{|c|}{$\begin{array}{c}\text { Funkcjonowanie badanych } \\
\text { po utracie słuchu }\end{array}$} & Liczba pacjentów \\
\hline Uczucia i emocje pozytywne & 15 \\
\hline Uczucia i emocje negatywne & 81 \\
\hline
\end{tabular}

Pacjenci przejawiali w tym okresie wysoki poziom lęku, który był tak demobilizujący, że każda aktywność, jak na przykład wyjście do sklepu lub rozmowa z nieznajomym wydawała się zadaniem niemożliwym do zrealizowania. Konsekwencje stopniowej utraty słuchu oraz nagłej głuchoty powodują, że sfera językowego funkcjonowania ulega znacznym zaburzeniom. Artykulacja staje się niewyraźna, momentami trudna do zrozumienia. Również realizacje na poziomie suprasegmentalnym są w pewnym stopniu zniekształcone, co może utrudniać tworzenie przejrzystych komunikatów. Osoby niesłyszące, ogłuchłe postlingwalnie dostrzegają wyraźne dysproporcje pomiędzy funkcjonowaniem osób prawidłowo słyszących w stosunku do nich samych. 20-osobowa grupa pacjentów rozpoczęła po utracie słuchu naukę odczytywania mowy z ust. Niestety, nie przyniosło to zamierzonych efektów; pacjenci jeszcze dotkliwiej odczuwali swoją niepełnosprawność słuchową, kiedy musieli prosić swych rozmówców o wyraźną artykulację, zwolnione tempo mowy lub wielokrotne powtarzanie wcześniej wygłoszonych kwestii. Często spotykali się ze zniecierpliwieniem oraz brakiem empatii. Potęgowało to uczucie frustracji oraz zagubienia i osamotnienia. Pacjenci zauważają, 
że często wśród najbliższych nie znajdują zrozumienia dla sytuacji, w której się znaleźli. Duża część pacjentów dotkliwie doświadcza pogorszenia lub zerwania więzi emocjonalnych z małżonką/małżonkiem oraz dziećmi i przyjaciółmi. Niemożność swobodnego komunikowania się oraz udzielania adekwatnych odpowiedzi na pytania generowane w określonej sytuacji społecznej powoduje, że doświadczenie wykluczenia społecznego staje się realne i bardzo prawdziwe.

Po implantacji wszczepem ślimakowym można zaobserwować wyraźne zmiany w badanej grupie. Użytkowanie wszczepu ślimakowego przywróciło większości pacjentów możliwość percepcji słuchowej otaczających dźwięków oraz dźwięków mowy. Podjęcie trudu systematycznej pooperacyjnej rehabilitacji przyniosło wymierne korzyści. Przede wszystkim poprawiła się jakość wymowy, można było zaobserwować pozytywne zmiany w zakresie jakości oraz natężenia tworzonego głosu. Nabyta autokontrola słuchowa przyczyniła się do "odzyskiwania” - utraconej w wyniku ogłuchnięcia - naturalnej barwy i brzmienia głosu. Możliwość rozumienia na drodze słuchowej tego, co mówią inne osoby przywróciła większości pacjentów wiarę we własne siły. Proces odzyskiwania i ponownej nauki utraconych umiejętności słuchowych warunkował swobodne posługiwanie się językiem mówionym, co było niezbędne w pracy zawodowej lub innych kontaktach społecznych. Funkcjonowanie w sferze rodzinnej również uległo poprawie. Pacjenci odczuwali pozytywne zmiany w zakresie poprawy relacji z najbliższymi osobami w rodzinie. Kontakty towarzyskie ze znajomymi i przyjaciółmi również stały się bardziej satysfakcjonujące. Pacjenci nauczyli się żyć ze wszczepem ślimakowym, który pomagał funkcjonować w codziennym życiu, dał szansę na odkrycie nowych możliwości w aspekcie słuchowego funkcjonowania. Ograniczenia związane z zaistniałą chorobą, której konsekwencją była utrata słuchu, przestały tak dotkliwie odciskać piętno na codziennym życiu. Badanie ankietowe jakości życia po implantacji w zakresie opisanych zmian pokazało, że ponad $80 \%$ pacjentów z badanej grupy (czynny udział w badaniu ankietowym wzięło 75 pacjentów) deklaruje polepszenie funkcjonowania $\mathrm{w}$ zakresie interakcji społecznych, a co za tym idzie - poprawę jakości życia (tab. 3).

Tabela 3

Jakość życia po implantacji wszczepem ślimakowym

\begin{tabular}{|l|c|}
\hline \multicolumn{1}{|c|}{ Jakość życia (subiektywna ocena) } & Liczba pacjentów \\
\hline Poprawa jakości życia & 68 \\
\hline Bez zmian & 2 \\
\hline Pogorszenie jakości życia & 5 \\
\hline
\end{tabular}


Pogorszenie jakości życia po implantacji wskazuje pięć osób. Duży wpływ na ten wynik mogły mieć nierealne oczekiwania pacjentów, którzy implant ślimakowy traktowali jako cud, a operacja wszczepienia wyżej wymienionego urządzenia miała być, $\mathrm{w}$ ich mniemaniu, zabiegiem przywracającym utracony słuch. Ta grupa pacjentów odnotowała również nasilenie szumów usznych i zawrotów głowy, które były już obecne przed operacją. Potraktowali oni implant ślimakowy jako swoiste panaceum na niedomagania organizmu. W związku z tym rozczarowanie, które narosło po zaimplantowaniu, spowodowało wzrost frustracji, złości oraz gniewu. Dwóch pacjentów nie zauważyło istotnych zmian po zaimplantowaniu, które mogłyby wpłynąć na polepszenie lub pogorszenie jakości życia.

Wyniki uzyskane po zastosowaniu kwestionariusza CES-D po zaimplantowaniu pokazują, że u 82 pacjentów objawy depresji wycofały się (tab. 4). Radość z odzyskanych choćby częściowo funkcji słuchowych oraz możliwości odbioru dźwięków, tylko za pośrednictwem drogi słuchowej, spowodowała, że coraz częściej w życiu pacjentów pojawiają się pozytywne uczucia i emocje (tab. 5).

Tabela 4

Funkcjonowanie badanych po zaimplantowaniu wszczepem ślimakowym CES-D

\begin{tabular}{|l|c|c|}
\hline $\begin{array}{c}\text { Funkcjonowanie badanych } \\
\text { po zaimplantowaniu }\end{array}$ & $\begin{array}{c}6 \text { miesięcy po aktywacji } \\
\text { części zewnętrznych } \\
(\mathrm{n}=96)\end{array}$ & $\begin{array}{c}24 \text { miesiące po aktywacji } \\
\text { części zewnętrznych } \\
(\mathrm{n}=96)\end{array}$ \\
\hline Brak depresji & 82 & 89 \\
\hline Objawy depresji & 14 & 7 \\
\hline
\end{tabular}

Tabela 5

Funkcjonowanie badanych po zaimplantowaniu wszczepem ślimakowym PANAS-PL

\begin{tabular}{|l|c|c|}
\hline $\begin{array}{c}\text { Funkcjonowanie badanych } \\
\text { po zaimplantowaniu }\end{array}$ & $\begin{array}{c}6 \text { miesięcy po aktywacji } \\
\text { części zewnętrznych } \\
(\mathrm{n}=96)\end{array}$ & $\begin{array}{c}24 \text { miesiące po aktywacji } \\
\text { części zewnętrznych } \\
(\mathrm{n}=96)\end{array}$ \\
\hline Uczucia i emocje pozytywne & 79 & 87 \\
\hline Uczucia i emocje negatywne & 17 & 9 \\
\hline
\end{tabular}

Osiągnięcie wzrostu poziomu umiejętności słuchowych w wyniku prowadzenia czynnego treningu słuchowego oraz coraz dłuższego czasu użytkowania wszczepu powoduje, że pacjenci czują się coraz pewniej w obszarach, które do tej pory były źródłem zakłopotania, lęku, czy frustracji. Funkcjonowanie $\mathrm{w}$ implancie ślimakowym pozytywnie zainspirowało większość pacjentów. Doświadczali dumy i radości z własnych osiągnięć, mieli w sobie 
gotowość do podejmowania nowych wyzwań życiowych w sferze zawodowo-osobistej. Duża część pacjentów deklarowała wzrost zainteresowania codziennymi sprawami, którym - w okresie wcześniejszym, będąc w kryzysie związanym z utratą słuchu - nie poświęcała żadnej uwagi. Większość pacjentów $\mathrm{w}$ badaniu ankietowym przyznaje, że akceptacja ze strony najbliższych umożliwiła przełamanie barier komunikacyjnych oraz psychicznych, które istnieją nawet po zaimplantowaniu. Przyznają również, że odzyskiwanie „dawnej” pełnionej roli w życiu społecznym przed utratą słuchu staje się realne dopiero po przejściu długiej drogi rehabilitacji pooperacyjnej. Kompleksowa rehabilitacja związana jest między innymi z nabyciem umiejętności przewartościowania oczekiwań wobec własnego życia oraz akceptacji swoich ograniczeń. Nabyta niepełnosprawność słuchowa ciągle istnieje i nie ma możliwości skutecznego jej wyleczenia. Użytkowanie implantu ślimakowego zredukowało część negatywnych konsekwencji związanych z utratą słuchu, lecz jakość słyszenia i rozumienia mowy w protezie nie zawsze jest zadowalająca. Można to zaobserwować w sytuacjach braku komfortu słuchowego (przebywanie w hałasie, większa liczba rozmówców w jednym czasie itp.), którego efektem jest ograniczone rozumienie.

\section{Dyskusja}

Przedstawione wyniki badań jednoznacznie wskazują, że implantacja wszczepem ślimakowym $\mathrm{w}$ grupie osób ogłuchłych postlingwalnie przynosi zadowalające efekty. Prowadzenie systematycznego treningu słuchowego przyczynia się do poprawy ilości oraz jakości percepcji dźwięków otoczenia oraz mowy na drodze słuchowej’. Jakość percepcji słuchowej w implancie ślimakowym jest bardzo ważna, ale $\mathrm{w}$ indywidualnym procesie wychodzenia z kryzysu równie ważne są cechy osobowości, poziom inteligencji, zdolność organizmu do kompensacji oraz motywacja do podjęcia trudu rehabilitacji ${ }^{10}$. Konstruktywne przystosowanie się do zaistniałych warunków pozwala łagodzić przebieg niepożądanych procesów związanych z żałobą po utracie czegoś tak cennego jak słuch ${ }^{11}$. Może to oznaczać, że po zaimplantowaniu należy stawiać sobie cele realne i możliwe do osiągnięcia, znajdując dla siebie takie sfery, gdzie można się optymalnie realizować. Radzenie sobie z indywidualnym poczuciem straty możliwe jest poprzez zjawisko kompensacji, które można osiągnąć stosując różne alternatywne sposoby. Dzięki takiej strategii

9 A. Aschendorff, N. Marangos, R. Laszig, Ergebnisse in der Rehabilitation erwachsener Cochlear - Implant - Patienten, WMW 1997, 147, s. 252-254.

${ }^{10}$ J. Kobosko, W. Jędrzejczak, Satisfaction With Cochlear Implants, s. 605-618.

11 P.G. Zimbardo, Psychologia i życie, Warszawa 1999, s. 211-220. 
depresja, która zazwyczaj towarzyszy tym negatywnym zmianom, znika, a w jej miejsce pojawia się wiara i nadzieja, że można żyć satysfakcjonująco nawet ze „sztucznym uchem”, jak pacjenci nazywają wszczep ślimakowy. Większość badanych osób zauważa pozytywne zmiany w swoim życiu już w okresie do 6 miesięcy po podłączeniu procesora mowy. Im dłuższy czas użytkowania wszczepu, tym obserwuje się wyraźny wzrost pozytywnego nastawienia do życia oraz innych ludzi. Możliwość odzyskania utraconej w wyniku choroby percepcji słuchowej powoduje, że pacjenci nie czują się już tak wykluczeni i zepchnięci na margines życia społecznego. Powraca chęć do życia, apetyt na nowe doświadczenia i gotowość na zmiany, która wypiera obniżony nastrój i depresyjne nastawienie do życia codziennego. Podobne głosy można odnaleźć w pracy Contrera i współpracowników ${ }^{12}$ oraz Karinen i współpracowników ${ }^{13}$. Pozytywne zmiany w życiu zawodowym, rodzinnym i społecznym po implantacji stają się czynnikiem motywującym do dalszej rehabilitacji. Pacjenci z głuchotą postlingwalną w większości przypadków zachowują poziom funkcjonowania językowego z czasów przed utratą słuchu. Jak podkreśla Damen i współpracownicy ${ }^{14}$ oraz Faber $^{15}$, poziom rozwoju i użycia mowy przed implantacją stanowi klucz do sukcesu. Posługiwanie się w satysfakcjonujący sposób mową oralną przed implantacją zwiększa szanse na pełniejsze wykorzystywanie informacji słuchowych dostarczanych dzięki implantowi. Poprawa funkcjonalnego słyszenia i rozumienia powoduje pełniejsze uczestnictwo w życiu społecznym, a dzięki temu pacjenci zauważają poprawę jakości życia w sferze kontaktów rodzinnych, zawodowych oraz w sposobach spędzania wolnego czasu. Fakt ten podkreślił również Souse i współpracownicy ${ }^{16}$. Część pacjentów deklarowała wyraźne pogorszenie jakości życia po implantacji. Może to być związane z nasileniem dolegliwości, które występowały już wcześniej, przed operacją. Ponadto, strach przed zabiegiem operacyjnym, świadomość możliwych zagrożeń ${ }^{17}$ wraz z depresyjnym nastawieniem do zaistniałej sytuacji mogła wzmocnić negatywne odczucia. Ta grupa pacjentów wymaga pełniejszej diagnozy.

${ }_{12}$ K.J. Contrera, J. Betz, Quality of life after intervention with a cochlear implant $r$ hearing aid, Laryngoscope, 2016 September, 126(9), s. 2110-2115.

${ }_{13}$ P.J. Karinen, M.J. Sorri, Cochlear implant patients and quality of live, Scand Audiol., 2001, 30(Suppl 52), s. 48-50.

${ }_{14}$ G.W. Damen, A.J. Beynon, P.F. Krabbe, Cochlear implantation and quality of life in postlingually deaf adults: long-term follow up, Otolaryngol Head Neck Surg, 2007, 136, s. 597-604.

${ }_{15}$ C.E. Faber, A.M. Grontved, Cochlear implantation and change in quality of live, Acta Otolaryngol, 2000, 543, s. 151-153.

16 A.F. Souse, M.I.V. Couto, Quality oflife and cochlear implant: results in adults with postlingual hearing loss, Braz J Otorhinolaryngol, 2017 July, 5, s. 30105-30152.

17 G.A. Stamation, E. Kynodimos, A. Sismanis, Complications of cochlear implantation in adults, Ann Otol Rhinol Laryngol, 2011, 120, s. 428-432. 


\section{Wnioski}

1. Implantacja wszczepem ślimakowym w grupie osób z głuchotą postlingwalną umożliwia percepcję słuchową dźwięków otoczenia oraz dźwięków mowy, co przyczynia się do poprawy jakości życia codziennego.

2. Funkcjonowanie w życiu społecznym i rodzinnym u większości pacjentów uległo poprawie po zaimplantowaniu, co zwiększa szanse na pełniejsze uczestnictwo w życiu społecznym i kulturalnym danej wspólnoty.

3. Występowanie indywidualnych trudności adaptacyjnych wraz z subiektywnym odczuciem związanym z pogorszeniem jakości życia po zaimplantowaniu może być związane ze wskaźnikami zdrowia psychicznego u poszczególnych pacjentów. Występujące i utrzymujące się długi czas - przed i po zaimplantowaniu wszczepem ślimakowym - dominujące negatywne uczucia i emocje oraz objawy depresyjne wymagają pogłębionej diagnozy.

\section{BIBLIOGRAFIA}

Aschendorff A., Marangos N., Laszig R., Ergebnisse in der Rehabilitation erwachsener Cochlear - Implant - Patienten, WMW 1997.

Contrera K.J., Betz J., Quality of life after intervention with a cochlear implant $r$ hearing aid, Laryngoscope, 2016 September, 126(9).

Czapiński J., Psychologia szczęścia - przegląd badań teorii cebulowej, Warszawa - Poznań 1992.

Damen G.W., Beynon A.J., Krabbe P.F., Cochlear implantation and quality of life in postlingually deaf adults: long-term follow up, Otolaryngol Head Neck Surg, 2007, 136.

Dziurowicz-Kozłowska A., Wokót pojęcia jakości życia, Psychologia Jakości Życia, 2002, 1.

Faber C.E., Grontved A.M., Cochlear implantation and change in quality of live, Acta Otolaryngol, 2000, 543.

Karinen P.J., Sorri M.J., Cochlear implant patients and quality of live, Scand Audiol., 2001, 30(Suppl 52).

Kobosko J., Jędrzejczak W., Satisfaction With Cochlear Implants in Postlingually Deaf Adults and Its Nonaudiological Predictors: Psychological Distress, Coping Strategies and Self Esteem, Ear Hear, 2015 September-October, 36(5).

Kowalik S., Pomiar jakości życia - kontrowersje teoretyczne, [w:] Pomiar i poczucie jakości życia u aktywnych zawodowo i bezrobotnych, red. A. Bańka, R. Derbis, Poznań 1995.

Kowalik S., Stosowana psychologia rehabilitacji, Warszawa 2018.

Psychologia kliniczna, red. L. Cierpiałkowska, H. Sęk, Warszawa 2005.

Radloff L., The CES-D Scale: A self-report depression for research in general population, Appl. Psychol. Measur., 1977, 1.

Souse A.F., Couto M.I.V., Quality of life and cochlear implant: results in adults with postlingual hearing loss, Braz J Otorhinolaryngol., 2017 July, 5.

Stamation G.A., Kynodimos E., Sismanis A., Complications of cochlear implantation in adults, Ann Otol Rhinol Laryngol, 2011, 120.

Watson D., Clark L.A., The PANAS-X: Manual for the positive and negative affect schedule, Expanded form, Iowa City 1994.

Zimbardo P.G., Psychologia i życie, Warszawa 1999. 